\title{
Chapter 2 \\ Beyond an Ugly Appearance: \\ Understanding the Physical Design \\ and Built Environment of Large \\ Housing Estates
}

\author{
Frank Wassenberg
}

\begin{abstract}
Large housing estates - and high-rise blocks in particular-are well-known for their problems. This chapter explores the extent to which physical form is responsible for causing the eventual failure of many large housing estates. Although the process of planning large housing estates in the post-World War II era is considered to have been well-thought out, it is also worth exploring how the design, size, form and appearance of these housing estates affected their negative perception and outcomes. The chapter investigates the relationships between the built environment of large housing estates, their local contexts and negative social outcomes commonly associated with estates. To understand this relationship, the chapter examines why high-rise apartment blocks and large housing estates were built the way they were, why problems are concentrated there and what is being done to combat the problems commonly experienced in large residential districts.
\end{abstract}

Keywords Large housing estates - High-rise - Urban renewal policies Physical appearance $\cdot$ Neighbourhood development

\subsection{Large Housing Estates Are Intriguing}

Everyone has an opinion about large housing estates. This could be an opinion about their most visible shapes, which are often high-rise blocks, characterised by a uniform repetition of cells. However, most opinion makers, nor scientists, nor policymakers do not live on such large estates themselves, and never visit them unless strictly necessary. Surprisingly, most of these large-scale estates have been carefully planned. Planners, scientists, architects and other experts have spent far

\author{
F. Wassenberg $(\bowtie)$ \\ Platform31, The Hague, The Netherlands \\ e-mail: frank.wassenberg@platform31.nl \\ F. Wassenberg \\ Delft University of Technology, Delft, The Netherlands \\ (C) The Author(s) 2018 \\ D. B. Hess et al. (eds.), Housing Estates in Europe, The Urban Book Series, \\ https://doi.org/10.1007/978-3-319-92813-5_2
}


more time studying ideas, design and construction than was the case with most other neighbourhoods, but this has not lead to the intended satisfaction and popularity of these estates.

Why is it that large housing estates, and high rises in particular, attract all this attention? Is it the failure of the form? Are they just considered ugly - not so by me, but by many citizens? Do most people prefer other types of dwellings, once they get choice? Is it the scale, the monotonous repetition, the (lack of) colour ('fifty shades of grey') or the one-size-fits-all appearance?

Large housing estates, particularly high rises, can be considered one of the most shining examples of well-thought-out urban designs ever: 'housing of tomorrow for the people of today'. However, since then tremendous problems have been observed, receiving particular attention from policymakers, urban practitioners and scientists. Sometimes, rigorous measures were inescapable, often soon after construction.

In this chapter, I focus on the physical perspective, realising that other points of view are just as important, but these are dealt with in other chapters of this book. Within the country chapters, all perspectives will be combined. I make use of my doctoral dissertation, in which I describe my experience with over 20 years interference with the issue (Wassenberg 2013).

Problematic or not, it is a fact that large housing estates do exist; in some countries, they are up to half of the housing stock. We have to cope with them and make them functional as an ordinary urban neighbourhood. When necessary, we have to consider ways to improve them. Sometimes to a lesser degree, but elsewhere major renewal approaches are inescapable. Fortunately, fine examples of minor and major renewals of large estates do exist.

This chapter describes both the glorious designs and expectations from when large housing estates were first built, the convergent fortunes of the estates once built, the numerous problems in the years following, and integrated approaches to renewing failing estates. The chapter starts with some general thoughts about large housing estates and high-rise blocks in particular. Afterwards, we elaborate on the roots of the construction of large housing estates, followed by their promising start. However, problems soon started occurring, mostly in Western European countries. Western Europe has had the most experience with integrated approaches for sustainable renewal of those estates.

\subsection{Reflections on Large Housing Estates}

The first question to raise is: 'What is a large housing estate?' Earlier studies pointed out that there is no universal definition for a housing estate, nor for a large housing estate (see: Power 1997; Dunleavy 1981; Turkington et al. 2004; van Kempen et al. 2005; Rowlands et al. 2009).

The British phrase 'housing estate' is not easily and equally translated into other languages, providing different connotations. In Germany and Austria, we can find many 'Siedlungen' or 'Wohnsiedlungen', but these have a connotation of their 
socialist advocates in the 1920s. The French 'cité's' or 'ensembles' are associated with remote post-war constructions in the notorious banlieue. The Dutch 'complex' associates with the administration unit of the owning housing associations. In Spanish, 'poligonos de vivienda' is the closest, which is clearly associated with Franco's dictatorship strategy of building large housing estates for blue-collar workers in major cities. 'Housing estate' is more a British English term, as in the United States and Australia, 'housing developments' and 'tract housing' are more widely used.

\subsubsection{Features of Housing Estates}

We distinguish ten features of housing estates:

1. Planned development: A housing estate is the result of urban planning, not of the organic growth of cities.

2. Urbanity: Housing estates can be found in urban or suburban areas, where houses have been built in large quantities.

3. Appearance: Housing estates are usually built by a single contractor in a limited period of time and according to one prevailing design, resulting in a uniform and distinct appearance.

4. Economy: The construction of adjoining similar dwellings in large amounts provides more housing at lower costs.

5. Building periods: Although the history of housing estates starts in the nineteenth century, most estates were built in the post-World War II decades. This is the period we focus on.

6. Housing types: Housing estates vary from single-family developments to large high-rise blocks.

7. Tenure: Housing estates can be owner-occupied, public (or social) housing and privately rented housing. A mix is possible.

8. Social equality: In the post-war decades, egalitarianism and uniformity prevailed over individualism and diversity: 'What is good for one, is good for all'.

9. Function: Housing estates usually contain dwellings. Only in large developments are support functions like neighbourhood centres, community services and schools included. Often, housing is clearly separated from other functions.

10. Location: Most housing estates were developed outside the then-existing city limits, where sufficient land was available and affordable. Some of these once-peripheral spots became central within cities, while others have remained isolated.

Next to these spatial characteristics, we can add one more, concerning the size, as we are talking about large housing estates. Estates may contain thousands of dwellings, depending on the local context; so, an average housing estate in Moscow or London will be larger than one in the provinces. However, housing estates are 
quite large scale within the local context. The larger the city, the larger an estate has to be to be considered as 'large' by locals.

\subsubsection{Defining Large Housing Estates and High Rises}

Combining all these thoughts, we can define a large housing estate as a group of housing distinct in form, built together as a single development on a large scale for the local context. High rises form an important and clearly visible part of large housing estates. High rises are commonly defined as when the number of floors is high enough that an elevator is legally required; in most cases, this is five or more. Most high rises were built in a limited time period. The country-specific chapters will illustrate this. Sometimes, disguised post-war estates do have very fundamental origins. The next section provides some background into this.

\subsection{The Roots of Large Housing Estates}

Any organised country in history has provided large housing estates. Increasing civilisation has historically led to urbanisation, and to upscaling of housing provision. The Romans built six storey high blocks, which must have been considered as mass housing by locals, as did other cultures like the Persians, Maya's and Chinese to name a few. Much later, industrialisation in the nineteenth century attracted masses of job seekers to expanding urban areas where new industries were being concentrated. Cities grew rapidly, providing housing for the masses and providing large housing estates. Vienna grew from 400,000 to 2 million over the second half of the nineteenth century. Here, the masses were housed in poorly equipped, large blocks, often rented by the bed. Up to $20 \%$ of all tenants rented a bed by the hour, sharing it with others during the day. Paris grew from 1 million in 1850 to almost 3 million by World War I. Glasgow saw its demographic base increase between 1801 and 1861 from 77,000 to 400,000, before exceeding 1 million by 1911. Emerging cities were not equipped for such large migrant inflows, which led to poverty, overcrowding, poor hygienic conditions, diseases and a host of other social miseries (Lévy-Vroelant et al. 2008). To combat the misery, housing conditions had to be improved. Several distinctive developments led to the construction of mass housing. We consider five of these.

\subsubsection{Philanthropists Take Action}

The first housing estates in the late 1800 s were built on a small scale by philanthropic aristocrats and utopian industrialists, in order to combat social injustice, 
provide healthy workforces, control urban diseases and reduce the risk of uprisings. Enlightened rich entrepreneurs provided decent housing for deserving workers and their families. Examples are New Lanark in Scotland, Agnetapark in Delft, the Netherlands, Lever's Port Sunlight in England, the Krupp estate in Berndorf, Austria and Le Creusot and Dolfus in Mulhouse, France. These examples are quite different from what we now consider to be large housing estates.

\subsubsection{Governments at Last Got Involved}

Gradually, but very slowly, governments became involved in housing (Pooley 1992). It was not until the late 1800s that increased concern about public health put housing on the national political agendas and led to housing acts being passed in many European countries around 1900. National governments got involved only after the World War I. The building industry had collapsed, and moreover, there was fear of uprising socialist parties, which were stimulated by the Russian revolution in 1917. State involvement only grew after 1945.

\subsubsection{Healthy Garden Cities}

Concerns about slum conditions stimulated the search for healthier urban and housing environments. Ebenezer Howard's influential 1898 plan for a 'Garden City' combined the best of 'town' and 'country' in small, low-density developments away from the overcrowded city. The 'garden suburb' of the 1920s and 1930s constituted a genuine housing form, built in response to the excesses of unregulated urbanisation. Renowned garden cities in England are Welwyn and Letchworth. Howard became the inspiration for the New Town Movement, which as a form of urban planning has had large impacts all around the world.

\subsubsection{Modern CIAM Architects}

Most dwelling construction followed traditional ideas in the inter-war years, but by the 1930s a more radical philosophy began to emerge. Das Neue Bauen had its roots in Germany, but was to be of great international influence, especially in the USSR. Stalin's Soviet Union provided a model with collective rental housing for workers on a large scale. This model was used in European countries under Communism and provided inspiration for Western European architects and planners, both between the world wars and in the first years after World War II. According to the principles of Modernism, architects and urban planners believed it 
was possible to construct a new and egalitarian society by providing dramatically improved housing and environmental conditions for the working classes.

From 1928 onwards, the Congrès Internationaux d'Architecture Moderne (CIAM) organised international congresses that were to have a major influence on the construction of large housing estates. Probably, its most prominent member was the Swiss architect Le Corbusier.

\subsubsection{A Housing Estate as a Planned Neighbourhood}

Architects and urban planners had thought not only about better housing units but also about better living environments than the slums with small, overcrowded and unhygienic housing on stuffy streets hidden from the daylight. Hall called the nineteenth-century slums the 'City of dreadful night', after the late nineteenthcentury poet James Thomson (Hall 1988). Polasky (2001) spoke of 'teeming, chaotic and congested cities, where the ever increasing number of workers who huddled in blind alleys and rookeries threatened urban order'.

Urban planning reformers embraced the neighbourhood unit planning idea of American planner Clarence Perry and the human ecologists of the Chicago School. Urban planning of the post-war large housing estates leaned heavily on these important neighbourhood planning ideas (Nyström 2006). Many post-war housing estates were built with the ideas that the neighbourhood was a unit; it would flourish by itself when houses and all the necessary services, like schools and neighbourhood centres were within the same unit or area. Post-war large housing estates were very orderly and well planned, contrary to the chaotic urban planning of the pre-war years, as depicted in Fig. 2.1.

\subsection{Glorious Estates}

\subsubsection{Mass Housing for Millions}

The three decades following the World War II are often considered the golden age of social housing, les trentes glorieuses, as the French call it. Millions of homes were built, the majority in large housing estates. Social housing estates were no longer aimed only at the working classes, but also at the middle classes, key workers and, otherwise, the lowest classes. Social housing policy allowed the majority of the population to share the wealth of the economic boom and was a key factor in the establishment of national welfare states, following Scandinavian examples (Scanlon et al. 2014).

It is interesting to note that the modern architects in Western Europe tested their first concepts of mid-rise blocks in the colonies of northern Africa. Avermaete and 

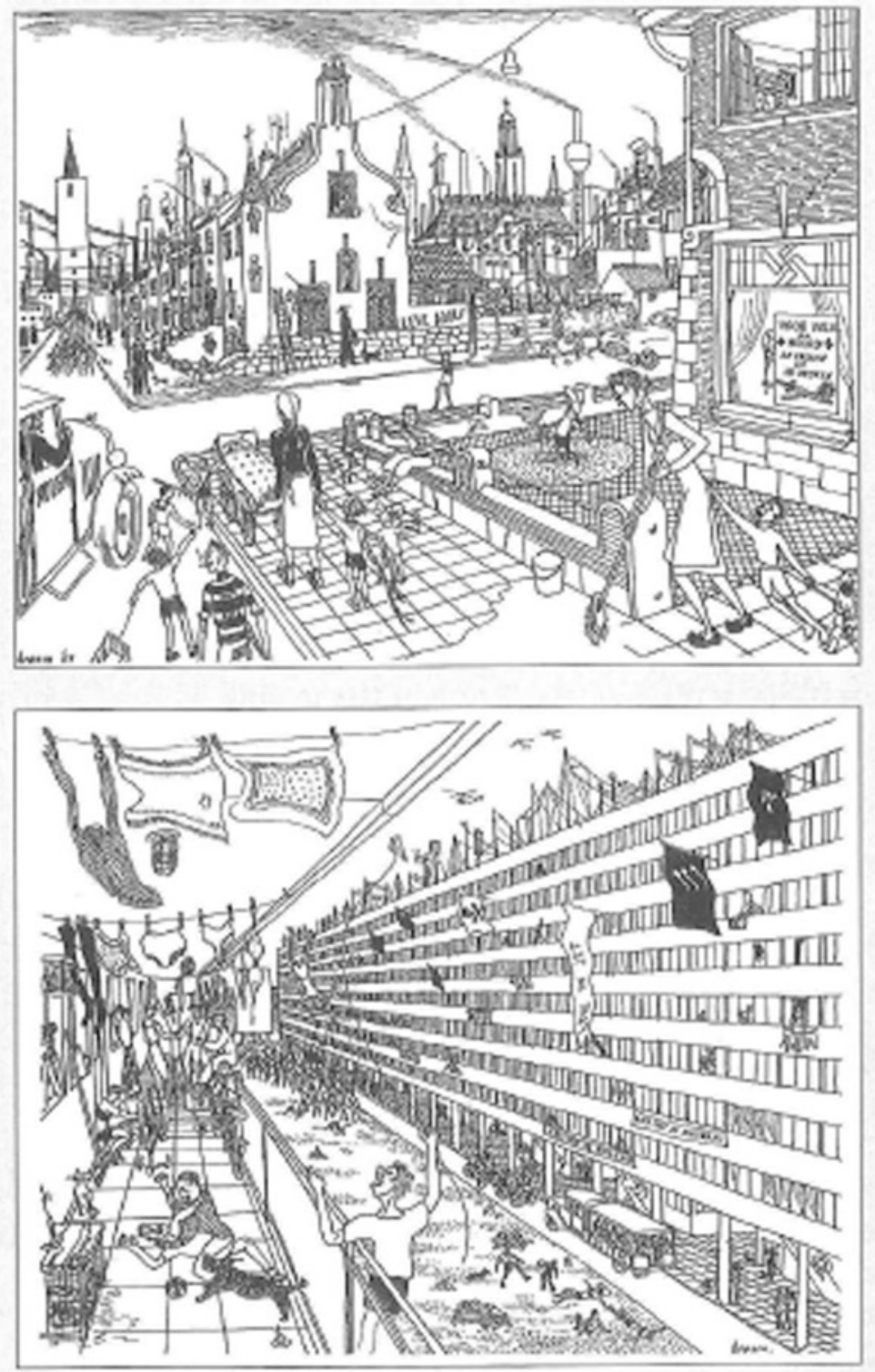

Fig. 2.1 Belgian architect Renaat Braem illustrates strikingly different views of modernist and traditional urbanists (1953, in: Declerck 2004); top: modern architects' view of traditional neighbourhoods. bottom: traditional views of modernistic estates

colleagues (2010) formulated this as follows: 'Modern modes of mass construction which were tested in North Africa in the 1940s and 1950s soon migrated to the peripheries of Western European cities where the all-too-familiar suburbs arose to 
accommodate hundreds of thousands of people. In many cases, the inhabitants living in the outskirts of Paris and London originated from the former colonies. Colonial history thus returned home to the European metropolises'. We can observe that many North Africans ended up in the modernist blocks, however, not in North Africa but in Western Europe's large housing estates.

Large housing estates have been constructed for a number of reasons. The origins of such estates can be found in the miserable living conditions found about four generations ago. Architects and urban planners knew what to do, and they designed spectacular solutions, but it was not until after the great devastations of World War II that governments developed a willingness to be involved in housing issues. The post-war baby boom and migration patterns increased housing scarcity tremendously, and housing received top political priority in many countries. Under government control, large housing estates were the result.

\subsubsection{Seven Motives for Building Large Housing Estates}

By the 1960s, a series of influences and pressures had coincided that can be regarded as the seven motives for building large mass housing estates across European countries (Turkington et al. 2004). These are as follows:

(1) reducing housing shortages caused by war damages, high birth rates, migration from the countryside to the cities, international migration and growing prosperity.

(2) technological improvements and labour-saving techniques that enabled homes to be built in volume and at speed. Building in concrete, the use of large prefabricated components, establishing housing factories on site and the rationalisation of the building process all made high-rise technically possible.

(3) the belief that architecture would contribute to a fair society. There was great confidence that 'Modernism' applied to housing and urban planning could deliver a more equal and fair society. The achievement of the egalitarian functional city represented a powerful expression of the belief that social development could be controlled more effectively than ever before.

(4) to save the countryside from mass sprawl, the belief that the new high-density housing would protect nature from urban sprawl associated with single-family houses (Mentzel 1989). Building high rises would provide more open space and reduce the pressure on agricultural land.

(5) a higher standard of living. It is often forgotten that in the early 1960s, the new flats were relatively luxurious and spacious, provided with such modern amenities as a hot and cold water supply, a shower or bath, central heating and a rubbish disposal system. Collective amenities such as childcare, laundry, shops and recreation facilities made high-rise living both comfortable and convenient. 
(6) status and competition, related to symbolism of high-rise housing. High-rise blocks were landmarks reflecting a town's urbanism and modernity. Municipal authorities and social housing providers competed with each other to acquire such symbolic buildings, and as a result, high-rise blocks can be found in almost every city in Europe. This status motive still exists in the form of the present competition to build the tallest skyscraper.

(7) governmental support. In Britain, large housing estates were associated with slum clearance and additional subsidies were provided to support building costs. In the Netherlands, 25\% extra subsidy was given in 1963 for prefab housing systems.

\subsection{Large Housing Estates: Similar Start, Divergent Outcomes}

Similar motives for the production of high-rise housing produced similar outcomes. The outcomes of the golden years for the construction of large housing estates are evident. Housing production peaked in the late 1960s and early 1970s, not coincidentally the same era where the construction of high-rise housing peaked. Mass housing on large estates was definitely supply-side construction; arguments had to do with production numbers. Research had determined what residents should want. This resulted in 'the ideal dwelling', to be produced in limited types and large quantities. Some figures illustrate this. In Hungary, the 15-Year Housing Development Plan of 1960 resulted in the construction of 1 million new homes, mostly in mass-produced high-rise blocks. In Sweden, high-rise housing dominated the famous Million Programme in 1964. The speed of construction tripled. In the Netherlands, it took $2000 \mathrm{~h}$ to build a traditional house, compared to only $600 \mathrm{~h}$ for a system-built construction (De Vreeze 1993). Figures on France show that the average time taken to produce a dwelling dropped from nearly two man-years in 1950 to 7 months in 1960. As a result, between 1960 and 1980, France built nine million dwellings, and it is evident that in any 4-year period from these decades, more homes were produced than in the 1920s and 1930s combined. Between 1966 and 1973, over $60 \%$ of all social-sector housing built in the Netherlands, and two-thirds of social housing in France consisted of high-rise blocks (Fig. 2.2).

An important feature of large housing estates was the provision of collective space for communal use, based on high expectations of people's mutual and collective behaviour (see Fig. 2.3). Such ideas fit particularly well with the Nordic welfare model, in which state-organised systems were designed to take care of their citizens, and with communist principles of communal provision practiced in eastern European countries.

Housing estates were produced in large quantities, at high speed and to uniform standards. Key elements were standardisation and repetition of construction 


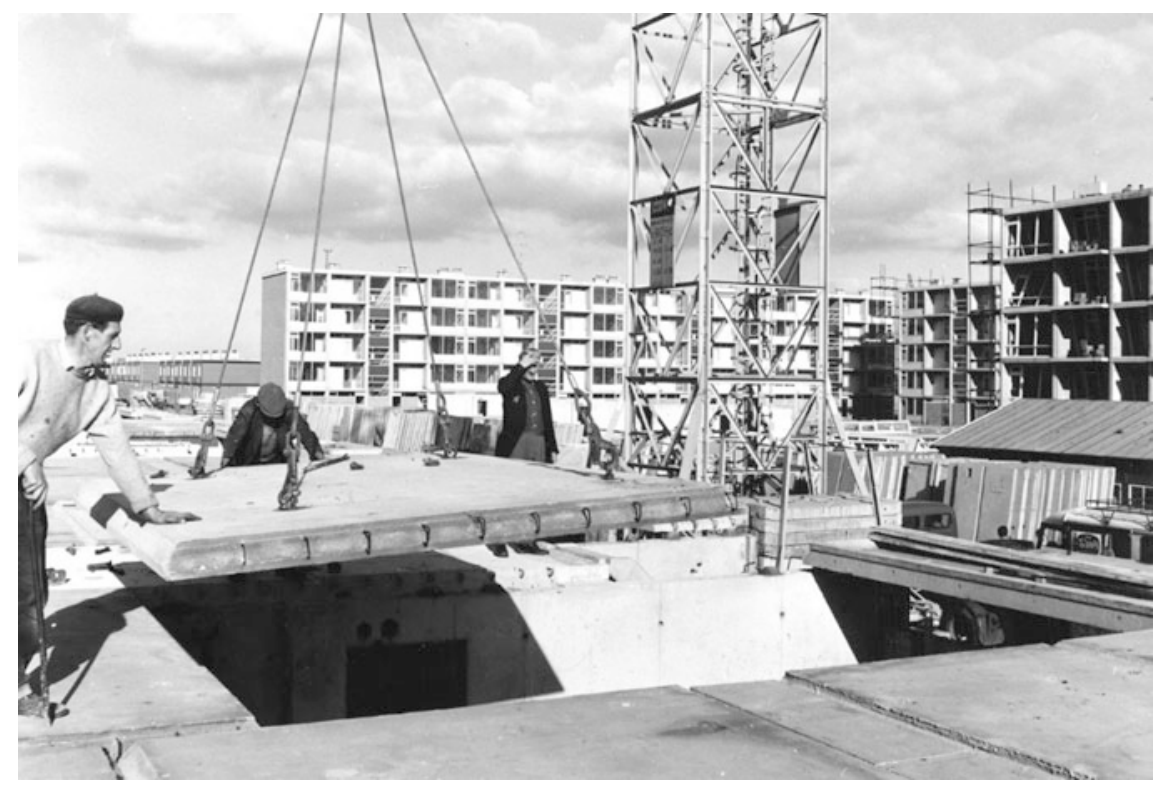

Fig. 2.2 New production methods sped up housing construction Photo by Fas Keuzenkamp, courtesy Delft University of Technology archives

patterns, with the use of prefabricated constructions from housing factories on the site. In Germany and Eastern Europe, post-war estates are often called Plattenbau, referring to the concrete panels used. One can say that traditional houses are 'built', while mass housing on large estates was 'produced'.

Post-war large housing estates were built at easy to acquire and inexpensive locations, namely on the outskirts of cities. Since then, siting has depended on local urban development; some housing estates are still far out of town, while others have been swallowed up by further urban expansions. In many countries, large housing estates are not limited to larger cities: many smaller cities and towns have their own large housing estates-large, that is, for their local context.

\subsubsection{The High-Rise Wave}

High-rise estates in western countries were built in a concentrated period, a high-rise wave, starting somewhere in the 1960s, and stopping rather suddenly some 10 years later. The period ended in England after a horrifying gas explosion (Ronan Point in East London) in the late 1960s, in the USA after a major debacle in St. Louis in the early 1970s (Pruitt-Igoe), and in the Netherlands, Western Germany and Sweden in the mid-1970s after it became clear that the market demanded something else. The wave of northern and western European countries peaked around 1970. 

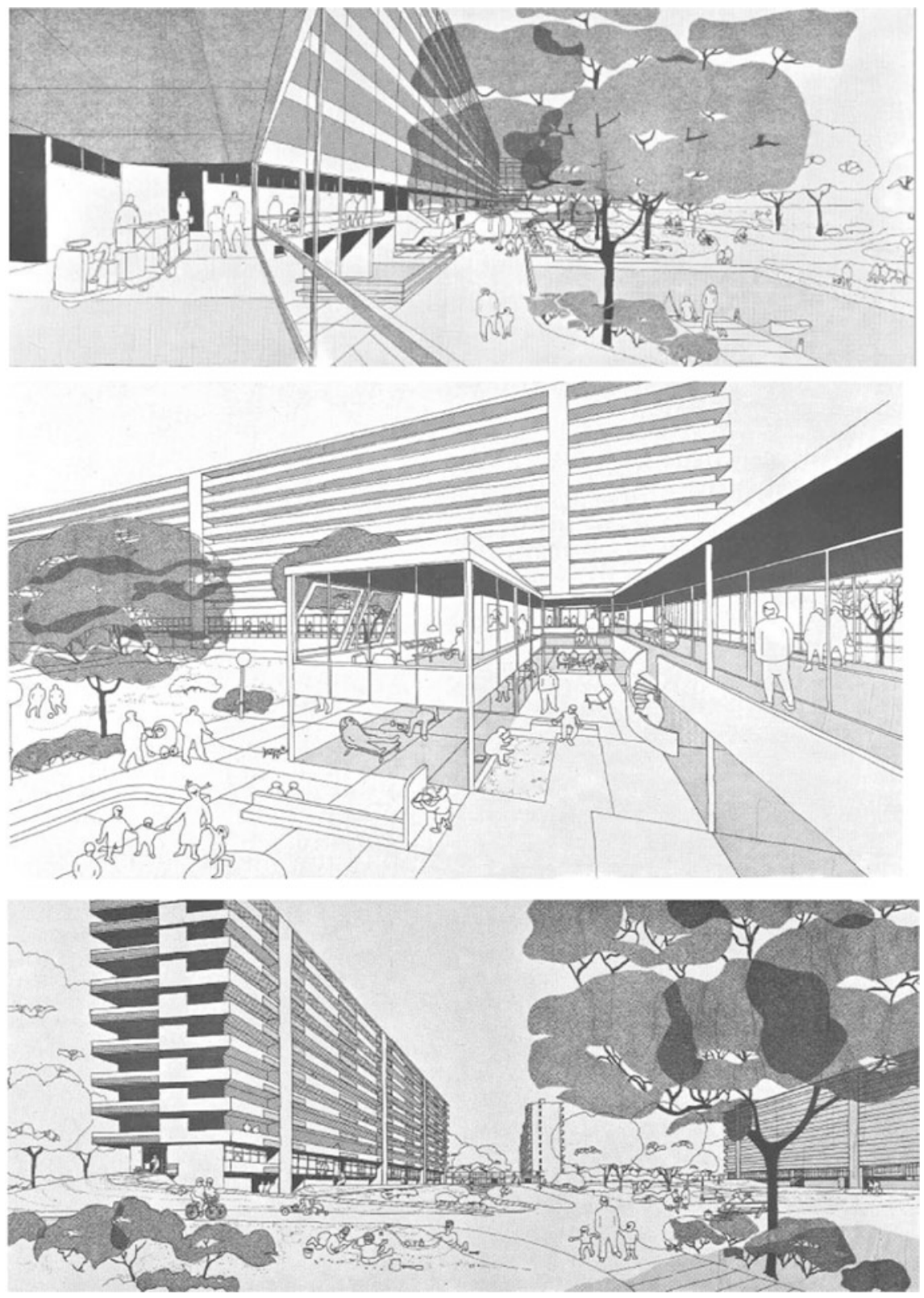

Fig. 2.3 Three depictions of social space in modernist housing estates. Source Gemeente Amsterdam, 1968 
After these respective waves, there was a remarkably sharp decline, caused by a radical anti-establishment shift in society, resulting in more demand-oriented planning. However, by that time, millions of dwellings on mass housing estates had been built. A commonality is the way they were planned: top-down, by planning departments and according to (sometimes scientific) research into what would be best for residents - but without consulting residents, who were (supposed to be) happy simply to get any dwelling in times of everlasting housing shortages.

In Eastern Europe, the construction of high-rise housing estates continued until the fall of the Berlin Wall in 1989, and in Southern Europe and Southeast Asia, there has been continuous construction of high-rise estates for the last 50 years. This is why more high-rise estates can be found in countries such as Spain, Italy, Ukraine and Hong Kong, than in Scandinavia, Germany, Britain and the USA.

After a standstill between the mid-1970s and the 1990s, new high-rise housing is again being constructed in western countries, following Asian initiatives in the Pacific and in Arab countries. This new high-rise housing, however, is no longer built on large housing estates, but mostly in separated tower blocks. What is remarkable is that these modern high-rise blocks are promoted with the same advantages and features as their predecessors: private living, extensive views, security and luxurious common facilities. Moreover, they are aimed at another population group, namely wealthy young or elderly urban-oriented citizens, not the working or middle-class families as in the 1960s. And the location differs: not on the outskirts of town, but in central and attractive locations: in the city centre, near transit stations or at the riverfront.

Post-war housing estates, culminating in the high-rise estates of the 1960s and early 1970s, represented the ideal housing of their era, egalitarian and modern dwellings that were spacious, comfortable and well designed. However, these qualities would be questioned in the subsequent era.

\subsubsection{There Were Critics, but No One Listened}

Considering the mass of criticism and problems that finally arose, did no one give criticism before mass housing construction? Criticism is easy when history has already shown you to be right, but what were the opinions beforehand? High-rise housing might appear to have been planned without any critics, but that was not the case.

The large housing estates, high rises in particular, were the ultimate culmination of the modern architecture of CIAM. The city of tomorrow for the people of today. One characteristic of CIAM was the emphasis on leadership. The architect, the urban planner and the politician had to decide what is best for mankind, so they did (or rather, they tried). One of the most famous critics of the top-down planned neighbourhood is, without a doubt, Jane Jacobs. In 1961, she published The Death and Life of Great American Cities, but it would be a decade or so before her work, and followers, became more mainstream. Jacobs would later be considered one of 
the most influential urban thinkers, with her plea for livelier urban areas, attractive streets and a concentration of activities, functions, inhabitants and passers-by. Cities should not be planned, but grow in an organic way. Seeing the obvious failure of too many planned, top-down, large neighbourhoods, it is not difficult to understand why she later acquired a wide range of followers. Nevertheless, early criticism was not enough, considering the seven motives were just too strong during the period of the high-rise wave, especially the everlasting housing shortage.

Did high rises meet people's demands? A constant factor during post-war urban planning was the almost total neglect of consumers' wishes. Planners and architects thought they knew what was good for people. Early critics like Dunleavy and Jephcott stated that the intended families with children did not want to live in flats at all. In the 1960s, Pearl Jephcott studied inhabitants of the well-known (and just finished) new towers of 'the Gorbals' in Glasgow and concluded that 'local authorities should discontinue this form of housing except for a limited range of carefully selected tenants' (Jephcott 1971 in; Mentzel 1989). Cooper Marcus and Hogue (1977), Gifford (2007) and Stewart (2009) provided an extensive literature overview that clearly shows that children are better off in low rises rather than high-rise housing. However, in the early years of high-rise construction, consumers' opinions were not heard, and the views of professionals held sway.

\subsubsection{Different Outcomes}

While similarities between countries in ideas and the construction of large housing estates were greater than their differences, developments afterwards followed more divergent outcomes. A clear geographical distinction across Europe can be drawn. Northern and Western European countries have developed a negative critique of high-rise living and estates, compared with Southern Europe where such housing is experienced as conventional. In both North and South, dwellings more often are owner occupied, or in cooperative housing, while in Western Europe more dwellings are rented, often in the social housing sector. This makes it easier for inhabitants to move away instead of staying and investing in the area. In Eastern European countries, living on a large housing estate is experienced as a 'normal' form of housing, but is increasingly problematic, especially in its technical quality and energy efficiency. It does not help that most dwellings have been sold to the then-inhabitants during the 1990s, without any maintenance experiences nor structures.

Most problems, analysis and interventions have been carried out in Western European countries. There, the problems turned out to be most dramatic. In these countries, there existed a series of so-called 'sink estates', where numerous and often terrible problems occurred. 


\subsection{Sink Estates}

\subsubsection{All Areas Develop, but Some Areas Get Deprived}

Estates are not static entities. They change when used by residents, visitors and local entrepreneurs. They age, wear out and need maintenance and renewal. Some neighbourhoods are always doing well, while others decline and become branded as a 'problem', 'disadvantaged', 'deprived' or 'concentrated' area. This refers to a downward process in which people who can afford it move out and make room for people in the lower social strata, whereby dwellings and streets deteriorate, crime and anti-social behaviour increase, services and businesses leave or go out of business, and the image of the neighbourhood worsens.

Cities are characterised by differences and inequalities. Variety and differentiation are part of urban life. However, when differences are too large, problems accumulate in too large and too heavy concentrations: such deprived areas exist in many forms (Fig. 2.4).

There is abundant literature explaining area developments and providing causes for deterioration. Van Beckhoven and colleagues (2009) provided an overview, including the findings of earlier scholars. They mentioned processes that are considered to happen more naturally and automatically (like the ecological school of succession, filtering and downgrading), while others emphasised the influence of human behaviour (with preferences, social cohesion, constraints and possibilities)

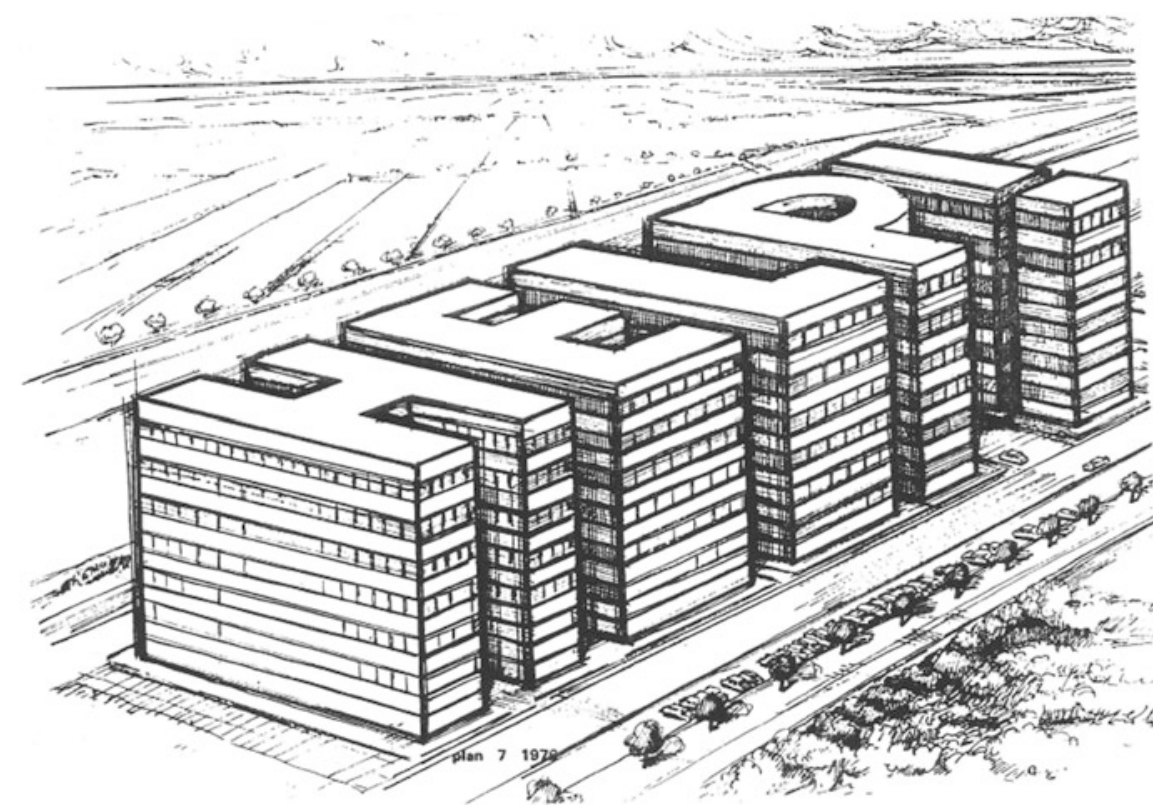

Fig. 2.4 High-rise housing in trouble. Source Figure in Plan 7, 1970 
or physical appearance (ugly buildings that cause social deterioration). Others focused on institutions and organisations (like management and processes of allocation).

\subsubsection{Cycles of Decline}

Large housing estates are best known by many observers for their problematic image, less popular housing, high crime rates, safety issues, broader quality-of-life issues, deprivation and decline. These are all well-known problems. Professionals and academics hurry to state that there are plenty of large estates that work well, where residents are satisfied, and problems are limited. In 'Mass housing in Europe' (2009), Rowlands et al. focus on these differences. Every estate has its own history and follows its own path. Nevertheless, there are plenty of similarities, on which I focus.

Problems do not occur on all estates, at least not at the same time and with the same intensity. Developments are dependent on factors of supply (initial quality, character and use), demand (preferences, resources and constraints), the available alternatives, external trends in society and policies that are possibly adopted or ignored. When all factors turn out negative, estates develop into sink estates, where increasing problems of all kinds become downward spirals of further deterioration. In most cases, neither a single problem nor a single cause can be indicated, but rather intricate combinations of causes and effects are responsible. Prak and Priemus (1986) developed a comprehensive model to explain why a process of decline, once it has begun, apparently leads of its own accord to further decline. They identified three cycles of decline: technical decline (affecting the estate), social decline (affecting tenants) and financial decline (affecting the operation of the estate). All three cycles may influence and reinforce each other and are also affected by external factors including government policies, wider social and economic trends and the policies of owners.

\subsubsection{Is It the Design?}

Similar spirals of decline have been analysed by other authors, including Power (1997) and Temkin and Rohe (1996). One of the most controversial questions concerns the impact of the urban form itself. Coleman's (1985) study 'Utopia on Trial' accused the architects and developers of mass housing estates of generating problems through bad design. However, while large high-rise estates were generally considered unattractive, the case for physical design determinism was unproven.

The question was also raised by Rowlands et al. (2009): Why are mass housing estates a problem? One obvious reason is that they provide - en masse - a housing type that does not reflect contemporary household preferences. However, the 
authors were reluctant to blame the physical layout of the mass housing estates and referred to many large estates that have satisfied residents. Adriaanse (2011) elaborated on some well-functioning large housing estates that are doing well in their local housing markets, despite their appearance. One of the main explanations she found lies in the set of mostly unwritten norms and values among inhabitants, tacit rules that maintain the quality of living.

Urban (2012) compared mass housing in seven metropolises around the world. He stated that differences show that design alone is not to blame for mass housing's mixed achievements. The buildings did not produce the social situations they came to stand for, but acted as vessels, conditioning rather than creating social relations. Similar buildings function well in one city but are catastrophic in another. This functioning is dependent on a range of factors.

\subsubsection{At Least, Design Plays a Role}

One estate is not the other, and the local context will always be different. It is a combination of housing-type, large-scale, urban design and location that make particular estates less popular places to live. When alternatives are available, people choose 'with their feet', and stay out or move out. Hirschman (1970) was among the first to elaborate on the conceptualisation of customers' choice, and how increasing choices affect behaviour.

Urban design causes problems like insecurity and lack of social control, due to the way the area was built (large, monotonous blocks, separate lanes for pedestrians, bikes and cars, and bushes beside the pavements). Newman (1972) came up with the often-cited idea of the (failing) defensible space in many of semi-public spaces: no-man's areas between home and the street. Moreover, the competitive position of high rises on the housing market is often not good. Once the reputation is low, social problems are on the increase. This might be a consequence of the allocation process, whereby households with little choice on the urban housing market end up in the least popular estates. These households may cause conflicts. Crime, vandalism and feelings of insecurity occur frequently precisely in this type of post-war district (Elsinga and Wassenberg 1991).

\subsection{Urban Renewal Policies}

Measures will usually be taken to combat problems. In some situations, early measures do the job. This usually happens only when there are favourable external circumstances, like a tightening housing market (limiting alternatives), supportive national policies (reshuffling of police forces, national subsidy schemes, employment support programmes, etc.) or general trends in society (economic growth, 
increasing employment, demographic shifts, etc.). However, these forces might also turn out to have a detrimental effect.

\subsubsection{Urban Renewal Policies}

Most European countries developed policies to renew cities and neighbourhoods (see Turkington and Watson 2015; Scanlon et al. 2014; Wassenberg 2015). Urban regeneration gradually became an integrated policy during the 1990s: City Policy (Politique de la Ville) in France, the National Strategy for Neighbourhood Renewal in England, Big City Policy (Grote Steden Beleid) in the Netherlands, the Metropolitan Development Initiative in Sweden and the Socially Integrative City (Soziale Stadt) in Germany. These territorial and integrative programmes combined physical, economic and social goals and strategies. Policies developed in a new way, towards a social mix of the population, to be achieved by a differentiated housing stock.

Moreover, years of urban centre upgrading paid out, resulting in more shops, cafés and restaurants, car-free streets, and festivals and attractions than twenty years ago. City life has just grown more pleasant. Urban popularity coincides with major trends like an increasing number of small households and small-scale service-oriented entrepreneurs, groups that often prefer city life.

The object of urban renewal differs per country. When global forces changed the worldwide industrial landscape, former heavily industrialised countries such as Britain, Germany and Belgium had to cope more with vacant industrial plots, which obviously needed transformation and restructuring. In France, Sweden and the Netherlands, a relatively large amount of social housing was produced in the decades following World War II. When prosperity rose and people could afford other types of housing, these mass housing neighbourhoods increasingly proved to be unpopular. In Southern European countries, owner occupancy rules and urban renewal activities focus on upgrading central districts. In Eastern Europe, all changes started only from the 1990s onwards after the political turnover. Despite general trends across Europe, local and national circumstances, histories and interests influence outcomes of the process of urban renewal (Lévy-Vroelant et al. 2008).

An interesting debate among scientists is whether urban renewal policies should be area-based, focusing on a better place to live, or people-based, focusing on better lives for residents. Physical renewal upgrades the area but offers no guarantee that residents' daily lives will improve, a situation that was found during the 1980s in Western European countries. Otherwise, socio-economic measures may improve residents' personal situations, but if successful people continuously move out, the area will stay deprived. This we can call the paradoxical relationship between territorial action and residential mobility. The challenge is to find the right balance between the two approaches, given the particular context of each area. 


\subsection{Renewing Large Housing Estates}

\subsubsection{Large Housing Estates: One Size Fits All}

Large housing estates were produced in big series and at high speed. Their contribution to alleviating housing shortages was substantial. They were planned by experts who followed general top-down planning ideas. These were uniform, corresponding to ideals of an egalitarian society. It was well-studied what the ideal dwelling should look like. The results of these studies were copied thousands of times, implemented by increasing technology and standardised labour-saving methods. People would easily feel at home. The location of work, leisure, recreation, school, housing or traffic was clear: every function was located on its own specific piece of land. Large housing estates anticipated the future; for everyone. One size fits all.

\subsubsection{From One Size to More Flavours}

However, society developed in another direction. People became educated and emancipated, many household types other than 'standard families' developed, prosperity grew and more room was needed for individual demands and styles of living. Uniformity, repetition and equality were the basic characteristics of the post-war society, the period in which many large housing estates were built. Diversity, individualism and choice would be the features of the following decades.

The larger and more one-size-fits-all the housing, the more vulnerable it is. This is exactly what happened with large housing estates: limited inconveniences became major problems, exacerbated by large size and uniformity.

All across Europe, restricted measures that prevailed in the 1980s and 1990s gradually made way for a more integrated urban renewal approach, in which several sectors are incorporated, major and minor measures are combined, long-term prospects for the area are mingled with the day-to-day worries of residents, and a range of participants are involved.

Policies are aimed at improving the quality of life for inhabitants and other users (safety, crime, pollution, vandalism and social cohesion), individual mobility (empowerment, education, jobs, language and debt control) and a financially sound exploitation of the housing stock. Achieving a social mix of groups within society is often also targeted. Policies are aimed at bringing ecological (energy, waste), social and economic sustainability. 


\subsubsection{Three Ingredients for an Integrated Approach}

Recovering estates can be characterised by three categories of ingredients. They have to differentiate the original one-size-fits-all character of the estate, which has proven to be vulnerable to changing circumstances. The ingredients for an integrated approach are based on creating more 'flavours' than provided by the one-size-fits-all model. Three categories of ingredients can be distinguished.

The first is bringing more differentiation within the area. This can be achieved by changing physical appearances, as well as by a better exploitation of positive current qualities, namely specific features that the area can be proud of and that outsiders often do not know about. The combination of brand new buildings and refurbished high rises may be another quality. More differentiation also can be achieved by allowing more room for the private initiatives of market actors and residents, such as residents who improve their (rented) homes themselves.

The second group of improvements is strengthening the relationships between residents and their housing environment, their neighbourhood and each other. Room for residents' initiatives can reinforce those relationships, just like the use of cultural values within the area. Another strategy is to keep the social climbers in the area by offering attractive housing alternatives.

The third group is more coherence in measures, through combinations of types of measures, both long-term and short-term major operations and day-to-day actions. It can also be achieved by using moments of communication (e.g. when rehousing) to deal with individual problems. More coherence is also necessary to limit spill-over effects, of which there will always be some. And more coherence is an ingredient for creating a broad social base to guarantee a long-term commitment. Major recovery schemes will easily last 20 years or more.

The successful recovery of large housing estates should lead to sustainable results. Once sustainable, an estate has enough internal vitality and flexibility to adjust to changing circumstances, uses and preferences. A sustainable urban area gradually adjusts to changing needs, uses and preferences of inhabitants and other users. Then, drastic renewal activities will no longer be necessary.

\subsection{Conclusion}

Physical design is never the only reason why a particular estate functions well or not. It is an ongoing debate whether physical elements contribute to this functioning. This chapter focused on these physical elements. At least, design matters, although it is more complicated than just the question of, 'Does it look ugly or not?'. This chapter explained why mass housing estates exist, including the most prominent type, the high-rise blocks. Seven strong motives contributed to the construction of millions of these kinds of dwellings across Europe. 
These high rises and other large housing estates exist and will be there for the next few decades. Whether we like them or not, we have to deal with this pan-European legacy. This chapter also showed prospects for large housing estates. They can be improved, if necessary. I want to end with an opportunity. During the 1960s-1980s, the large housing estates were developed to house working or middle-class families with children, as an appealing alternative for the small and outdated apartments of those days. However, when alternative family housing was built, these families did not opt for high rises. Nowadays, the situation is different. There are plenty of family houses in the suburbs, while most of the new households are small in size, often preferring urban life. A growing number of households are elderly, opting for ground floor flats instead of houses with stairs. Once improved, existing high rises and other large housing estates could meet the changing needs of households, offering all floors as 'ground floors' with elevator access, and a central location for services and jobs. Practices have shown that the sometimes 'ugly appearance' of estates can be transformed into aesthetically pleasing blocks. In this way, once-disguised large housing estates can transform into community assets.

\section{References}

Adriaanse C (2011) On measuring and explaining neighbourhood success. A behavioural economic approach. IOS Press, Amsterdam

Avermaete T, Karakayali S, Osten M (2010) Colonial modern, aestetics of the past-rebellions for the future. Black Dog Publishing, London

Coleman A (1985) Utopia on trial. Hilary Shipman, London

Cooper Marcus C, Hogue L (1977) Design guidelines for high-rise family housing. In: Stroudsburg P (ed) Human response to tall buildings. Dowden, Hutchinson \& Ross

De Vreeze N (1993) Woningbouw, inspiratie en ambities. Nationale Woningraad, Almere

Declerck N (2004) Belgium, impact of modernism in a divided country. In: Turkington R, van Kempen R, Wassenberg F (eds) High-rise housing in Europe. Delft University Presss, Delft

Dunleavy P (1981) The politics of mass housing in Britain, 1947-1975. Clarendon Press, Oxford

Elsinga M, Wassenberg F (1991) Tackling crime and vandalism on post-war housing estates: the Dutch approach. Netherlands J Hous Built Environ 6(2):159-175

Gifford R (2007) The consequences of living in high-rise buildings. Arch Sci Rev 50(1):2-17

Hall P (1988) Cities of tomorrow. An intellectual history of urban planning and design in the twentieth century. Basil Blackwell, Oxford

Hirschmann A (1970) Exit, voice and loyalty. Cambridge University Press, Cambridge

Jephcott P (1971) Homes in high flats. Some of the human problems in-volved in multi-storey housing. In Edinburgh

Lévy-Vroelant C, Reinprecht C, Wassenberg F (2008) Learning from history, changes and path dependency. Housing Strategies in Europe. LSE, London

Mentzel M (1989) Bijlmermeer als grensverleggend ideaal. Delft University Press, Delft

Newman O (1972) Defensible space: crime prevention through urban design. Macmillan, New York

Nyström L (2006) Neighbourhood centres in Europe: yesterday, today and tomorrow. Special Issue Built Environ 32(1):1-102

Polasky J (2001) Transplanting and rooting workers in London and Brussels: a comparative study. J Mod Hist 73:528-560 
Pooley CG (1992) Housing strategies in Europe, 1880-1930. Leicester University Press, Leicester, London, New York

Power A (1997) Estates on the edge: the social consequences of mass housing in Northern Europe. Macmillan, London

Prak NL, Priemus H (1986) A model for the analysis of the decline of post-war housing. Int J Urban Reg Res 10(1):1-17

Rowlands R, Musterd S, van Kempen R (2009) Mass housing in Europe, multiple faces of development, change and response. Palgrave Macmillan, Basingstroke

Scanlon K, Whitehead C, Fernández Arrigoitia M (2014) Social housing in Europe. Wiley, Blackwell

Stewart BT (2009) Inhabiting towers on the edge; creating a livable land-scape in Toronto's tower neighbourhoods. University of Berkeley, Berkeley

Temkin K, Rohe WM (1996) Neighbourhood change and urban policy. J Plan Educ Res 15:159170

Turkington R, van Kempen R, Wassenberg F (2004) High-rise housing in Europe: current trends and future prospects. Delft University Press, Delft

Turkington R, Watson C (2015) Renewing Europe's housing. The Policy Press, Bristol

Urban F (2012) Tower and slab, histories of global mass housing. Routledge, London/New York van Beckhoven E, Bolt G, van Kempen R (2009) Theories of neighbour-hood change and decline. In: Rowlands R, Musterd S, van Kempen R (eds) Mass housing in Europe. Palgrave Macmillan van Kempen R, Dekker K, Hall S, Tosics I (2005) Restructuring large housing estates in Europerestructuring and resistance inside the welfare industry. Policy Press, University of Bristol, Bristol

Wassenberg F (2013) Large housing estates: ideas, rise, fall and recovery. TU Delft, IOS Press, Amsterdam

Wassenberg F (2015) Meeting the British housing challenge: Dutch experiences and reflections. In: Crookston M (ed) Built environment, meeting the housing challenge: British experience, European lessons, vol 41, pp 211-226

Open Access This chapter is licensed under the terms of the Creative Commons Attribution 4.0 International License (http://creativecommons.org/licenses/by/4.0/), which permits use, sharing, adaptation, distribution and reproduction in any medium or format, as long as you give appropriate credit to the original author(s) and the source, provide a link to the Creative Commons license and indicate if changes were made.

The images or other third party material in this chapter are included in the chapter's Creative Commons license, unless indicated otherwise in a credit line to the material. If material is not included in the chapter's Creative Commons license and your intended use is not permitted by statutory regulation or exceeds the permitted use, you will need to obtain permission directly from the copyright holder. 